\title{
NATURAL DISASTER SHOCKS AND MACROECONOMIC GROWTH IN ASIA: EVIDENCE FOR TYPHOONS AND DROUGHTS
}

Emmanuel Alano and Minsoo Lee

NO. 503

December 2016
ADB ECONOMICS WORKING PAPER SERIES 
ADB Economics Working Paper Series

\section{Natural Disaster Shocks and Macroeconomic Growth in Asia: Evidence for Typhoons and Droughts}

Emmanuel Alano and Minsoo Lee

No. 503 | December 2016
Emmanuel Alano (ealano.consultant@adb.org) is a consultant and Minsoo Lee (mlee@adb.org) is a senior economist at the Economic Research and Regional Cooperation Department of the Asian Development Bank. 
Creative Commons Attribution 3.0 IGO license (CC BY 3.0 IGO)

(c) 2016 Asian Development Bank

6 ADB Avenue, Mandaluyong City, 1550 Metro Manila, Philippines

Tel +632 632 4444; Fax +6326362444

www.adb.org

Some rights reserved. Published in 2016.

Printed in the Philippines.

ISSN 2313-6537 (Print), 2313-6545 (e-ISSN)

Publication Stock No. WPS168584-2

Cataloging-In-Publication Data

Asian Development Bank.

Natural disaster shocks and macroeconomic growth in Asia: Evidence for typhoons and droughts.

Mandaluyong City, Philippines: Asian Development Bank, 2016.

1. Asia. 2. Climate impact. 3. Drought. 4. Natural disaster. 5. Typhoon. I. Asian Development Bank.

The views expressed in this publication are those of the authors and do not necessarily reflect the views and policies of the Asian Development Bank (ADB) or its Board of Governors or the governments they represent.

ADB does not guarantee the accuracy of the data included in this publication and accepts no responsibility for any consequence of their use. The mention of specific companies or products of manufacturers does not imply that they are endorsed or recommended by ADB in preference to others of a similar nature that are not mentioned.

By making any designation of or reference to a particular territory or geographic area, or by using the term "country" in this document, $A D B$ does not intend to make any judgments as to the legal or other status of any territory or area.

This work is available under the Creative Commons Attribution 3.0 IGO license (CC BY 3.0 IGO)

https://creativecommons.org/licenses/by/3.0/igo/. By using the content of this publication, you agree to be bound by the terms of this license.

This CC license does not apply to non-ADB copyright materials in this publication. If the material is attributed to another source, please contact the copyright owner or publisher of that source for permission to reproduce it. $A D B$ cannot be held liable for any claims that arise as a result of your use of the material.

Attribution-You should always acknowledge ADB as the source using the following format:

[Author]. [Year of publication]. [Title of the work in italics]. [City of publication]: [Publisher]. (c) ADB. [URL or DOI] [license].

Translations-Any translations you create should carry the following disclaimer:

Originally published by ADB in English under the title [title in italics]. (c) ADB. [URL or DOI] [license]. The quality of the translation and its coherence with the original text is the sole responsibility of the translator. The English original of this work is the only official version.

Adaptations-Any adaptations you create should carry the following disclaimer:

This is an adaptation of an original work titled [title in italics]. (c) ADB. [URL or DOI][license]. The views expressed here are those of the authors and do not necessarily reflect the views and policies of ADB or its Board of Governors or the governments they represent. ADB does not endorse this work or guarantee the accuracy of the data included in this publication and accepts no responsibility for any consequence of their use.

Please contact pubsmarketing@adb.org if you have questions or comments with respect to content, or if you wish to obtain copyright permission for your intended use that does not fall within these terms, or for permission to use the ADB logo.

Notes:

1. In this publication, “\$” refers to US dollars.

2. Corrigenda to ADB publications may be found at http://www.adb.org/publications/corrigenda 


\section{CONTENTS}

TABLES AND FIGURES

ABSTRACT

$\begin{array}{ll}\text { I. INTRODUCTION } & 1\end{array}$

A. $\quad$ Effects of Natural Disasters to the Economy 4

B. Effects on Tourism $\quad 11$

II. ADAPTATION TO NATURAL DISASTER SHOCKS 12

A. Migration and Urbanization 13

$\begin{array}{ll}\text { B. Risk Sharing } & 13\end{array}$

III. POLICY RECOMMENDATIONS

$\begin{array}{ll}\text { IV. CONCLUSION } & 15\end{array}$

$\begin{array}{ll}\text { REFERENCES } & 17\end{array}$ 


\section{TABLES AND FIGURES}

\section{TABLES}

$1 \quad$ Estimated Total Damages by Disaster Type, 1960-2015 2

$2 \quad$ Estimated Total Damages due to Climate-Related Disasters by Region, 1960-2015

3 Effects of Cyclones and Other Shocks to Gross Domestic Product Per Capita

$4 \quad$ Global Estimates of Macroeconomic Impacts of Natural Disaster Shocks 6

5 Macroeconomic Impacts in Selected Developing Asian Countries: Temperature Variation vis-à-vis Tropical Cyclone Shocks

$6 \quad$ Estimates of the Wind Intensity-Damage Function

$7 \quad$ Estimated Increase in Mean Damages under Climate Change Scenarios 9

8 Effect of Tropical Cyclones on Tourism in the Caribbean, 1995-2006 12

Box Table: Average Effects a Year after Typhoon Exposure in the Philippines

\section{FIGURES}

Frequency of Natural Disasters, 1900-2015 (EM-DAT) 


\begin{abstract}
Climate-related natural disaster shocks are expected to rise as the earth is getting warmer, which will adversely affect growth prospects globally. Current robust estimates of the effects of typhoons and droughts point to both short- and long-term declines in national incomes compared to predisaster trends and economic effects likely to persist up to 2 decades. Using the typhoon landfalls and damage in Asia, we analyze the wind-damage relationship and find damages to gross domestic product increase by $2.3 \%$ for an increase in maximum wind speed. The extreme projected temperature rise in Representative Concentration Pathway (RCP) 8.5 will result in higher damage by more than 50\% in 2100. Vulnerable developing Asian economies could expect dampened growth with significant impacts on agriculture and tourism, a concern that may roll back years of development gains and exacerbate inequality. To cope with increasing disaster risks, both short-term adaptation strategies like relocation, government transfers, and other social safety nets, as well as long-term strategies like disaster insurance or similar ex ante mechanisms are needed.
\end{abstract}

Keywords: Asia, climate impact, drought, natural disaster, typhoon

JEL codes: $130, \mathrm{Q} 54$ 


\section{INTRODUCTION}

Risks associated with extreme events or shocks (heat waves, extreme precipitation, and coastal flooding) will continue to increase as the global mean temperature rises (IPCC 2014). Climate change, warmer sea temperatures in particular, will result in extreme weather patterns and more frequent highintensity storms in selected ocean basins (Mei et al. 2015; Mendelsohn et al. 2012).

Climate-related natural disasters are expected to rise as the earth is getting warmer with the prospect of significant negative impacts on economic growth. Analyzing 750 empirical estimates, Klomp and Valckx (2014) show negative effects on economic growth per capita with developing countries severely affected by climatic shocks. Felbermayr and Gröschl (2014) find that natural disasters reduce per capita gross domestic product (GDP) by up to 6.8\% on impact or in the year they occur. ${ }^{1}$ A separate study also reports that both typhoons and floods negatively affect not only per capita GDP but also the debt ratio (Acevedo 2014). ${ }^{2}$ Vulnerable economies like the Pacific islands could expect growth to drop by 0.7 percentage points due to damage equivalent to $1 \%$ of GDP in the year of the disaster (Cabezon et al. 2015).

More than 7,000 major disasters have been recorded in the Emergency Events Database (EMDAT) since 1970, causing at least $\$ 2$ trillion in damages, killing at least 2.5 million people, and adversely affecting societies. ${ }^{3}$ Many researchers claim that extreme weather events have become more frequent and severe as a result of global warming. ${ }^{4}$ An example is the destruction caused by Typhoon Haiyan in 2013, one of the strongest recorded typhoons to make landfall, resulting in a total economic loss of around $\$ 10$ billion (EM-DAT) (see text box on the Philippines and natural disasters). The Philippines is no stranger to natural disasters, and Haiyan is the strongest tropical cyclone to ever hit the country and left 6,300 people dead and damaged over 1 million houses (NDRRMC 2013). Climate disasters have become a concern with the likelihood of rolling back years of development gains and exacerbate inequality (Karim 2016, Victoriano 2015).

Plotting the occurrence of all natural disasters (climate related and geophysical) from the EMDAT database, there is a clear increasing trend of storms and floods (see figure on page 2). By limiting the period of observation from 1960 to 2015, there is in most regions of the world an upward trend in climate-related events, including drought, extreme temperature, flood, storm, landslide, and wildfire.

1 A disaster is defined by the IPCC (2012) as "severe alterations in the normal functioning of a community or a society due to hazardous physical events interacting with vulnerable social conditions, leading to widespread adverse human, material, economic, or environmental effects that require immediate emergency response to satisfy critical human needs and that may require external support for recovery."

2 Also called hurricane in the Atlantic and cyclone in the Indian and South Pacific Ocean. These terms are used interchangeably in this paper.

3 The EM-DAT, maintained by the Centre for Research on the Epidemiology of Disasters (CRED) at the Catholic University of Louvain, Belgium, is the most widely used database for research on disasters. Established in 1973, CRED has compiled data on global disasters since 1900. See EM-DAT website at http://www.emdat.be/

4 Studies in Herring et al. (2015) show that anthropogenic activity (greenhouse gas emissions and land use) influenced specific weather and climate events in 2014. 


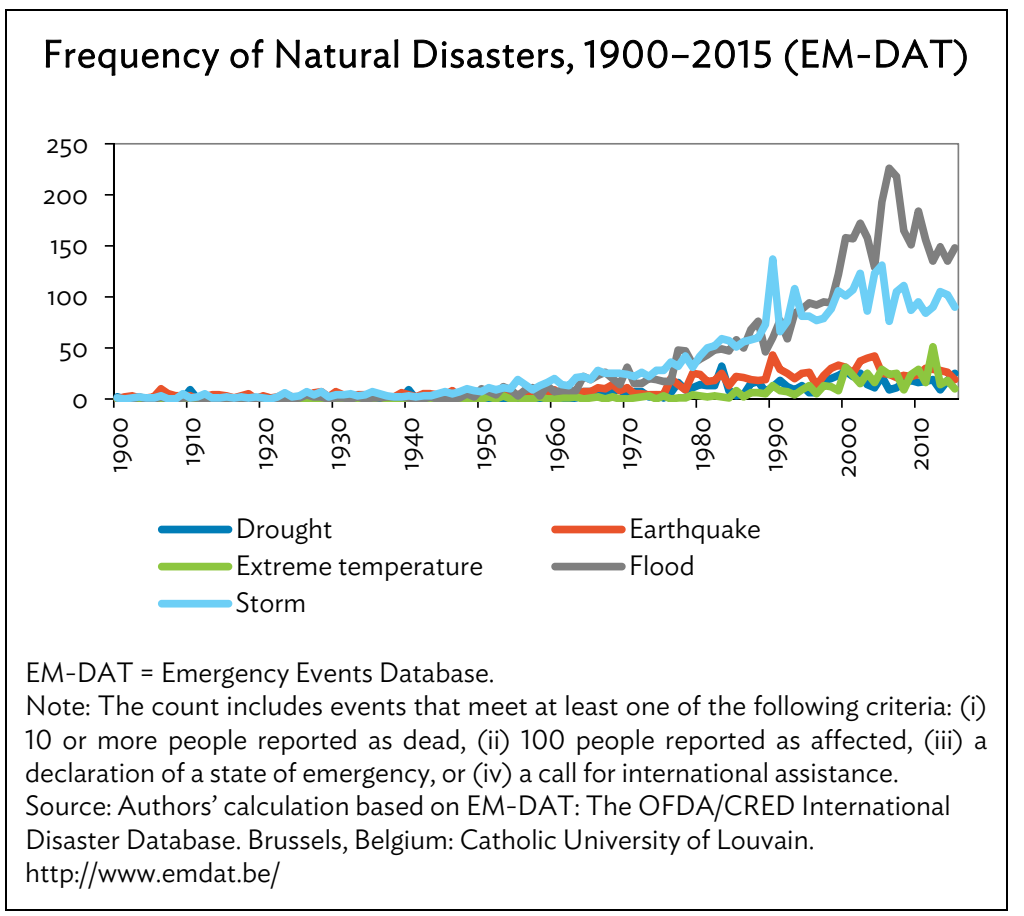

In Table 1, we see that earthquakes and storms generated the most damage to social and physical infrastructure. This includes catastrophic events like Hurricane Katrina in 2005, the Great East Japan earthquake in 2011, and Typhoon Haiyan in 2013. Aside from the lives lost, estimated total damages from climate-related disasters are staggering. From 1960 to 2015, storms caused at least $\$ 1.04$ trillion in damages and floods $\$ 696$ billion. Earthquakes, on the other hand, caused $\$ 771$ billion in damages.

\section{Table 1: Estimated Total Damages by Disaster Type, 1960-2015} (\$ billion)

\begin{tabular}{lc}
\hline Disaster Type & Total Damages \\
\hline Storm & 1,043 \\
Earthquake & 771 \\
Flood & 696 \\
Extreme temperature & 60 \\
Wildfire & 58 \\
Landslide & 9 \\
Drought & 0.1 \\
\hline & \\
Note: The count includes events that meet at least one of the following \\
criteria: (i) 10 or more people reported as dead, (ii) 100 people reported as \\
affected, (iii) a declaration of a state of emergency, or (iv) a call for \\
international assistance. \\
Source: Authors' calculation based on EM-DAT: The OFDA/CRED \\
International Disaster Database. Brussels, Belgium: Catholic University \\
of Louvain. http://www.emdat.be/
\end{tabular}

Developing countries, especially the low- and middle-income economies, are most at risk and where most vulnerable populations are located. Data from EM-DAT show that since 1960, 99\% of the affected population ( $87 \%$ middle income, $12 \%$ low income) and $97 \%$ of deaths caused by disasters (64\% middle income, 32\% low income) are in developing economies. Weighted by land area and population, small island states are exposed to more frequent natural disasters (Laframboise and 
Acevedo 2014). In terms of total damages caused by climate-related disasters (storms, drought, flood, extreme temperature, and wildfire), advanced economies were the hardest hit, mainly due to the higher cost of physical capital and infrastructure, followed by developing Asia (Table 2). Within the region, East Asia has the largest damages in United States (US) dollar terms. ${ }^{5}$

\section{Table 2: Estimated Total Damages due to Climate-Related Disasters by Region, 1960-2015} (\$ billion)

\begin{tabular}{lc}
\hline Region & Total Damages \\
\hline Advanced economies (OECD) & 1,160 \\
Developing Asia & 610 \\
East Asia & 374 \\
South Asia & 122 \\
Southeast Asia & 108 \\
Central Asia & 3 \\
The Pacific & 2 \\
Latin America and the Caribbean & 141 \\
Rest of the world & 57 \\
Middle East and North Africa & 26 \\
Sub-Saharan Africa & 14 \\
\hline \multicolumn{2}{l}{ OECD = Organisation for Economic Co-operation and Development. } \\
Source: Authors' calculation based on EM-DAT: The OFDA/CRED International \\
Disaster Database. Brussels, Belgium: Catholic University of Louvain. \\
http://www.emdat.be/
\end{tabular}

Due to their geographical location and archipelagic features, most of the low-income countries and small states, particularly in Sub-Saharan Africa and Pacific island states, are vulnerable to natural disasters. From 1985 to 2015, these countries were hit almost twice as often by climate-related disasters like floods, storms, and droughts (Farid et al. 2016). Among the Asian countries included in the World Risk Report since 2011 as having the highest disaster risks are Pacific island states like Vanuatu, Tonga, Solomon Islands, Timor-Leste, and Papua New Guinea as well as archipelagic countries like the Philippines. ${ }^{6}$ The proportion of the domestic population affected by natural disasters is also higher compared with high-income countries, particularly for small developing and low-lying coastal states. Within these countries, the poorest 25th percentile of countries, mostly in Sub-Saharan Africa, faces the highest natural disaster risks (Farid et al. 2016).

Climate-related natural disasters and temperature rise harm growth and exacerbate poverty in developing countries. Natural disasters may reduce developing country GDP growth by an estimated 1-3 percentage points, depending on the type of disaster. ${ }^{7}$ Temperature rise is also linked to lower growth, for example, Dell, Jones, and Olken (2012) find that in poor countries a $1^{\circ} \mathrm{C}$ rise in temperature from a country's annual mean temperature reduces economic growth by 1.3 percentage points on average, mainly by reducing agricultural output. Results from Lee, Villaruel, and Gaspar (2016) show the projected reduction of developing Asia's average per capita income level by $11 \%$ in 2100 under the

5 Includes Japan; the Republic of Korea; Hong Kong, China; Taipei,China; and the PRC.

6 Created by the United Nations University Institute for Environment and Human Security (UNU-EHS), the World Risk Report was started in 2011 and indicates the risk of disaster due to extreme natural events for 171 countries. It is available at http://www.worldriskreport.org/

7 See Farid et al. (2016) for macroeconomic impacts specifically, Raddatz (2007) and Loayza et al. (2012) on climatic disasters, Fomby, Ikeda, and Loayza (2009, 2013) on severe droughts, Acevedo (2014) on impacts for the Caribbean, and Cabezon et al. (2015) on the Pacific Islands. These studies combine EM-DAT data and exogenous variables. 
RCP8.5 scenario. ${ }^{8}$ Increasing temperature and rainfall volatility together with extreme weather events reduce agricultural productivity in low-income countries, an important growth channel given agriculture's large share in output in these countries (Farid et al. 2016). However, the study by Lee, Villaruel, and Gaspar (2016) confirms that aside from agricultural production, industrial production and investment are potential channels through which temperature significantly affects the overall economic productivity. Climate change and natural disaster risks worsen poverty due to loss of productive economic assets combined with limited savings (Hallegatte et al. 2015) and food vulnerability. Countries with weak institutions and unstable domestic food production as measured by food supply per capita growth tend to experience frequent food crises, while countries with sound macroeconomic fundamentals such as low fiscal deficit and higher food reserves experience a lower likelihood of a food crisis (Adedeji, Gieck-Bricco, and Kehayova 2016).

\section{A. Effects of Natural Disasters to the Economy}

\section{Typhoons}

The distribution of intense cyclone events is expected to shift toward fewer low-intensity cyclones but more frequent high-intensity events. Modeling studies project substantial increases in the frequency of the most intense cyclones, with an increase of about 20\% in the precipitation rate within 100 kilometers of the storm center (Knutson et al. 2010). The average typhoon intensity is also projected to increase by an additional $14 \%$ by 2100 (Mei et al. 2015).

The observed increase in sea surface temperatures has led to concerns about more intense cyclones. Historical records indicate that the greatest damage during cyclones results from storm surges. The scientific evidence to date suggests that increased sea surface temperature will intensify cyclone activity and heighten storm surges. Surges will be further elevated by a rising sea level due to thermal expansion and melting of ice caps (World Bank 2016).

A large number of empirical studies in the literature on the effects of natural disasters on economic growth focus on four hypotheses:

(i) A natural disaster might permanently set a country on a lower growth path (no recovery).

(ii) It might temporarily derail growth only to get back to its predisaster trend (recovery to trend).

(iii) It might lead to even greater growth, as reconstruction enables new investment to replace destroyed assets (build back better).

(iv) It might not only stimulate growth but also replace whatever outdated infrastructure was holding the country back with more modern and efficient capital goods (creative destruction).

Hsiang and Jina (2014) disentangle these hypotheses and assert that growth effects brought on by tropical cyclone strikes linger for almost 2 decades, with economies not recovering in the long run. Using 60 years of cyclone (in terms of wind speed) and economic data to estimate the long-term effects of climatic disasters on output, they find that national incomes substantially decline compared to predisaster trends and economic recovery does not happen for 20 years both for poor and rich

8 Scenario with extreme projected temperature rise should the world fail to meet the 2015 United Nations Climate Change Conference (COP21) targets. See note in Table 7. 
countries (Table 3). Devastating cyclones like Hurricane Katrina or Typhoon Haiyan can have longerlasting effects than a financial crisis. Reductions in per capita GDP range from 3.6\% to 14.9\% lasting for 2 decades. Projected estimates of monetary damages from cyclones up to 2100 range from $6 \%$ of GDP or $\$ 860$ billion for the case of the US to $83 \%$ of GDP or $\$ 300$ billion for the Philippines.

\section{Table 3: Effects of Cyclones and Other Shocks to Gross Domestic Product Per Capita}

\begin{tabular}{lrrr}
\hline Event Type & $\begin{array}{c}\text { Effect on } \\
\text { Income }\end{array}$ & Observed After & $\begin{array}{r}\text { In-Sample } \\
\text { Probability }\end{array}$ \\
\hline Temperature increase $(+1 \circ \mathrm{C})^{* a}$ & $-1.0 \%$ & 10 years & $6.4 \%$ \\
Temperature increase $\left(>1 \circ \mathrm{C}\right.$, SSP5) ${ }^{* * b}$ & $-23.0 \%$ & $>20$ years & $\ldots$ \\
& & $($ by 2100$)$ & \\
Civil warc & $-3.0 \%$ & 10 years & $6.3 \%$ \\
Tax increase $\left(+1 \%\right.$ GDP) ${ }^{* * * d}$ & $-3.1 \%$ & 4 years & $+16.8 \%$ \\
1 standard deviation cyclone & $-3.6 \%$ & 20 years & $14.4 \%$ \\
Currency crisisc & $-4.0 \%$ & 10 years & $34.7 \%$ \\
Weakening executive constraints & $-4.0 \%$ & 10 years & $3.7 \%$ \\
90th percentile cyclone & $-7.4 \%$ & 20 years & $5.8 \%$ \\
Banking crisisc & $-7.5 \%$ & 10 years & $15.7 \%$ \\
Financial crisis & $-9.0 \%$ & 2 years & $<0.1 \%$ \\
99th percentile cyclone & $-14.9 \%$ & 20 years & $0.6 \%$ \\
\hline
\end{tabular}

$\ldots=$ data not available, GDP = gross domestic product, SSP5 = Shared Socio-economic Pathway 5.

* Poor countries only. ${ }^{* *}$ Poor and rich countries. ${ }^{* *}$ United States only. +Number of quarters with any tax change.

a Dell, Melissa, Benjamin Jones, and Benjamin Olken. 2012. "Temperature Shocks and Economic Growth: Evidence from the Last Half Century." American Economic Journal: Macroeconomics 4 (3): 66-95.

b Burke, Marshall, Solomon Hsiang, and Edward Miguel. 2015. "Global Non-linear Effect of Temperature on Economic Production." Nature 527 (7577): 235-39.

c Cerra, Valerie, and Sweta Chaman Saxena. 2008. "Growth Dynamics: The Myth of Economic Recovery." American Economic Review 98 (1): 439-57.

d Romer, Christina, and David Romer. 2010. "The Macroeconomic Effects of Tax Changes: Estimates Based on a New Measure of Fiscal Shocks.” American Economic Review 100 (3): 763-801.

e Reinhart, Carmen, and Kenneth Rogoff. 2009. "The Aftermath of Financial Crises." American Economic Review 99 (2): 466-72.

Source: Adapted from Hsiang, Solomon, and Amir Jina. 2014. "The Causal Effect of Environmental Catastrophe on Long Run Economic Growth: Evidence from 6,700 Cyclones.” National Bureau of Economic Research Working Paper No. 20352.

Various studies have tackled the disaster-development nexus and generated estimates of global effects on GDP levels and per capita growth. Whereas the majority of these studies used EMDAT data as instrumental variables in growth regressions, generating some conflicting positive and negative results, more recent panel studies used a combination of EM-DAT data and exogenous variables such as wind speed and pressure for tropical cyclones and precipitation indices for droughts, uncorrelated with income measures such as GDP, to estimate output effects. This recent research also reported more robust results. Table 4 presents some of these studies. ${ }^{9}$ While Hsiang and Jina (2014) estimated long-run effects up to 2 decades and projections until 2090, others only provided short-run effects either on the year of impact or after 5 years, further evidence that damage from disaster shocks are not limited to immediate or direct effects.

Using a comprehensive database of disaster events and their physical intensities called GeoMet, Felbermayr and Gröschl (2014) find robust and substantial negative effects of natural disasters on economic growth which is similar to estimates generated by Fomby, Ikeda, and Loayza

9 Except for Loayza et al. (2012) who used EM-DAT data for the analysis. Other studies with positive results used crosssectional analysis. 
(2013); however, there was no evidence of a subsequent temporary boom. Their results show that an average storm reduces output growth by $0.16 \%$ but a $5 \%$ strongest storm by $1.75 \%$. A separate study by Mendelsohn et al. (2012) estimates that tropical cyclones reduce current global output by $\$ 26$ billion or $0.04 \%$ every year which is projected to double to almost $\$ 56$ billion by the end of this century.

Table 4: Global Estimates of Macroeconomic Impacts of Natural Disaster Shocks

\begin{tabular}{|c|c|c|c|}
\hline Study & Natural Disaster & $\begin{array}{c}\text { Effect on Income } \\
\text { (GDP per capita growth) } \\
(\%)\end{array}$ & Observed After \\
\hline \multirow[t]{3}{*}{$\begin{array}{l}\text { Hsiang and Jina } \\
\text { (2014) }\end{array}$} & $\begin{array}{l}1 \text { standard deviation tropical } \\
\text { cyclone }\end{array}$ & -3.6 & 20 years \\
\hline & 90th percentile cyclone & -7.4 & 20 years \\
\hline & 99th percentile cyclone & -14.9 & 20 years \\
\hline Felbermayr and & average cyclone & -0.16 & on impact \\
\hline \multirow[t]{2}{*}{ Gröschl (2014) } & 95th percentile cyclone & -1.75 & on impact \\
\hline & 95th percentile drought & -0.34 & on impact \\
\hline Loayza et al. (2012) & Droughts & $\begin{array}{l}-0.6 \\
-3.0\end{array}$ & $\begin{array}{l}1 \text { year } \\
5 \text { years }\end{array}$ \\
\hline $\begin{array}{l}\text { Mendelsohn et al. } \\
\text { (2012) }\end{array}$ & Tropical cyclones & $\begin{array}{c}\$ 26 \text { billion or } 0.04 \% \text { of } \\
\text { current global GDP, } \$ 56 \\
\text { billion by } 2100\end{array}$ & annual \\
\hline Fomby, Ikeda, and & Droughts & -1.7 & year of the event \\
\hline Loayza (2009) & Storms & -0.3 & year of impact \\
\hline
\end{tabular}

GDP = gross domestic product.

Source: Authors' compilation from cited studies.

By performing counterfactuals using their estimates to see what would happen if there were no cyclones from 1950 to 2008, Hsiang and Jina (2014) found that world GDP growth would have been $1.4 \%$ higher per year. In selected developing Asian economies, typhoons have resulted in significant "lost growth" for the period from 1970 to 2010 of as high as 7.3\% of GDP per capita in the Philippines (Table 5). Together with macroeconomic effects of temperature variation by 2100 , the estimated damage from tropical cyclones, which can exacerbate poverty and undermine social welfare (Laframboise and Acevedo 2014), can dampen growth and put considerable economic pressure especially on vulnerable populations in developing Asian economies.

\section{Typhoon Intensity and Damages in Asia}

The previous sections discussed the effects of typhoon shocks on macroeconomic growth rates and levels. The "damage functions" or the elasticity of damage to GDP by typhoon intensity (as represented by wind speed) has also been extensively studied and estimated as these are used in climate change research, particularly in integrated assessment models. Using data on hurricanes in the US, various studies estimated elasticity at 3.8 (Schmidt, Kemfert, and Höppe 2010), 5 (Mendelsohn et al. 2012), between 6 and 8 (Bouwer and Botzen 2011), and 9 (Nordhaus 2010). In the Caribbean, Acevedo (2016) estimated it at 2 for nonlandfall and 3.2 for landfall cyclones.

The best-track data for selected Asian economies were taken from the International Best Track Archive for Climate Stewardship (IBTrACS) with information on maximum wind speed as well 
as minimum pressure for the duration of the typhoon. ${ }^{10}$ Typhoons which made landfall were identified by overlaying the IBTrACS data within a global grid. Data on damages were taken from the EM-DAT database." GDP-level data were taken from the World Bank's World Development Indicators.

\section{Table 5: Macroeconomic Impacts in Selected Developing Asian Countries: Temperature Variation vis-à-vis Tropical Cyclone Shocks}

\begin{tabular}{|c|c|c|c|c|c|}
\hline & \multicolumn{2}{|c|}{$\begin{array}{c}\text { Temperature Effects on } \\
\text { GDP Per Capita Growth by } \\
2100 \\
(\%)\end{array}$} & \multicolumn{2}{|c|}{$\begin{array}{c}\text { Estimated Loss Using 5\% } \\
\text { Discount Rate by } 2090\end{array}$} & \multirow{2}{*}{$\begin{array}{c}\text { Cyclone Climate } \\
\text { Growth Penalty } \\
\text { ("Lost” Growth), } \\
1970-2010 \\
\text { GDP per capita } \\
\text { growth, } \%\end{array}$} \\
\hline & RCP8.5 & RCP2.6 & $\begin{array}{l}\text { \$ billion, } 2010 \\
\text { PPP }\end{array}$ & $\begin{array}{l}\% \text { of GDP, } \\
2010 \text { PPP* }\end{array}$ & \\
\hline Philippines & -4.2 & -1.0 & -299.3 & 81.5 & -7.28 \\
\hline Viet Nam & -4.9 & -1.2 & -160.1 & 57.9 & $\ldots$ \\
\hline Thailand & -5.6 & -1.3 & -140.6 & 24.0 & -2.17 \\
\hline Indonesia & -4.4 & -0.9 & -10.9 & 1.1 & -1.57 \\
\hline Malaysia & -4.8 & -1.1 & -9.8 & 2.4 & -0.25 \\
\hline Cambodia & -5.7 & -1.4 & -9.3 & 30.6 & $\ldots$ \\
\hline Lao PDR & -4.7 & -1.1 & -9.2 & 58.4 & $\ldots$ \\
\hline Developing Asia & -2.5 & -0.5 & $\ldots$ & $\ldots$ & $\ldots$ \\
\hline
\end{tabular}

$\ldots=$ data not available, GDP = gross domestic product, Lao PDR = Lao People's Democratic Republic, PPP = purchasing power parity, $\mathrm{RCP}=$ Representative Concentration Pathway.

* GDP 2010 PPP from World Development Indicators.

Sources: Authors' compilation from Hsiang, Solomon, and Amir Jina. 2014. "The Causal Effect of Environmental Catastrophe on Long Run Economic Growth: Evidence from 6,700 Cyclones." National Bureau of Economic Research Working Paper No. 20352; Lee, Minsoo, Mai Lin Villaruel, and Raymond Gaspar. 2016. "Effects of Temperature Shocks on Economic Growth and Welfare in Asia." ADB Economics Working Paper Series No. 501. Manila: Asian Development Bank.

This paper uses a modified wind-damage function, a log-log model estimated using panel fixed effects, adopted from Nordhaus (2010) and Acevedo (2016): $:^{12}$

$$
\ln \left(\text { Damages }_{i j t} / G D P_{i j t}\right)=\alpha+\beta \ln \left(\text { Wind }_{i j t}\right)+\sigma \text { Year }_{t}+\mu_{j}+\epsilon_{i j t}
$$

where Damages/GDP for each typhoon $i$ in country $j$ at year $t$ is regressed on the maximum Wind speed achieved by each typhoon in the sample and a time trend Year. $\mu_{j}$ captures time-invariant country fixed effects and $\varepsilon_{i j t}$ is the error term. The sample includes data on typhoons that made landfall from 1977 to 2014 for 10 economies with 113 observations.

Results in Table 6 indicate that a 1\% increase in typhoon intensity (wind speed in meters per second) results in an approximately $2.3 \%$ increase in the damages-to-GDP ratio. Intuitively, it also

10 Based on Knapp et al. (2010). Includes economies in developing Asia (Cambodia; India; Lao People's Democratic Republic; Myanmar; Philippines; PRC; Solomon Islands; Taipei,China; and Vanuatu) and Japan.

1 Estimated damages in US dollars, which is the total of insured and noninsured losses from various sources. This include amount of damages to property, crops, and livestock.

12 Alternatively, using a log-linear model, this paper finds that the semi-elasticity of maximum wind speed to damages is 0.0535 . Hsiang and Narita (2012) estimate a semi-elasticity of 0.010 showing that a 1.9 knots per hour ( 1 meter/second) increase results in a 10\% increase in damages. 
shows that both category 1 and 2 hurricanes exhibit increasing damage as the wind speed thresholds intensify. ${ }^{13}$ Estimates from this paper show that in Asia, the elasticity is about 2.3. This approximates results from empirical studies that indicate damage as a function of the square or cube of wind speed.

Table 6: Estimates of the Wind Intensity-Damage Function

\begin{tabular}{lcccccc}
\hline & $\begin{array}{c}(1) \\
\text { Pooled } \\
\text { Vn(D) }\end{array}$ & $\begin{array}{c}(2) \\
\text { Pooled } \\
\operatorname{Ln}(\mathrm{D} / \mathrm{GDP})\end{array}$ & $\begin{array}{c}(3) \\
\text { Damage } \\
\operatorname{Ln}(\mathrm{D})\end{array}$ & $\begin{array}{c}(4) \\
\text { Damage/GDP } \\
\operatorname{Ln}(\mathrm{D} / \mathrm{GDP})\end{array}$ & $\begin{array}{c}(5) \\
\text { Cat 1 } \\
\operatorname{Ln}(\mathrm{D} / \mathrm{GDP})\end{array}$ & $\begin{array}{c}(6) \\
\text { Cat 2 } \\
\operatorname{Ln}(\mathrm{D} / \mathrm{GDP})\end{array}$ \\
\hline Log(maximum & $1.7378^{*}$ & $2.3940^{* *}$ & $2.4561^{* * *}$ & $2.3487^{* *}$ & $2.4656^{* *}$ & $6.9843^{*}$ \\
wind speed) & & & & & & \\
Year & $0.0777^{* * *}$ & $-0.0593^{* * *}$ & $0.0810^{* *}$ & -0.0260 & -0.0367 & -0.0142 \\
Constant & $-1.5 \mathrm{e}^{+02^{* * *}}$ & $98.6914^{* * *}$ & $-1.5 \mathrm{e}^{+02^{* *}}$ & 32.2594 & 52.8588 & -14.7882 \\
$\mathrm{R}^{2}$ & 0.2112 & 0.1262 & 0.1981 & 0.0707 & 0.0809 & 0.3629 \\
Observations & 113 & 109 & 109 & 109 & 81 & 20 \\
Countries & 10 & 10 & 10 & 10 & 10 & 10 \\
Fixed effects & $\mathrm{No}$ & $\mathrm{No}$ & Yes & Yes & Yes & Yes \\
\hline
\end{tabular}

$\mathrm{D}=$ damage, $\mathrm{GDP}=$ gross domestic product.

${ }^{*} p<0.1,{ }^{* *} p<0.05,{ }^{* * *} p<0.01$.

Source: Authors' calculations.

With global warming, scientists believe that typhoons may further intensify. Emanuel (2005) finds that with warmer sea surface temperatures comes the possibility of stronger storms. This increase in intensity further increases the damages and costs to countries in developing Asia regularly hit by this type of disaster shocks.

To approximate the increase in damages from typhoons due to global warming by 2100 , the following parameters were used: ${ }^{14}$

$$
\Delta\left(\text { Damages }_{t} / G D P_{t}\right)=\left[\left(1+\gamma \theta_{t}\left(T_{t}\right)^{\beta}-1\right) * 100\right]
$$

where $\gamma$ is the semi-elasticity of maximum wind speed relative to changes in the sea surface temperature, $\vartheta$ is the elasticity of sea surface temperature to a change in global temperature $(T)$, and $\theta$ is the wind-damage elasticity estimated above (2.3). This study uses the same $y$ that Nordhaus (2010) and Acevedo (2016) use, $\gamma=3.5 \%$, and $\vartheta$ assumes a 1:1 change in sea surface temperature with a change in $T$ since the Representative Concentration Pathways (RCPs) do not project decadal changes in sea surface temperature.

Estimation results in Table 7 show that mean damages in Asia will increase by $21 \%$ by 2100 using the same sea surface temperature as Nordhaus $\left(2.5^{\circ} \mathrm{C}\right)$. Using projected temperature changes (low, mean, and high) under the RCP2.6 scenario, mean damages increase in the range from 5\% to $13 \%$. Higher damages as high as 53\% result under extreme temperature changes in the RCP8.5 scenario. By performing a sensitivity analysis using a higher $\gamma$ and lower $\vartheta$, the range of damages is essentially the same as the results from the RCP scenarios, from $5 \%$ to $56 \% .^{15}$

13 For easy reference, the Saffir-Simpson scale was used. See NOAA website at http://www.nhc.noaa.gov/aboutsshws.php

14 Modified equation adopted from Acevedo (2016) and Nordhaus (2010).

15 Higher $\gamma$ is from Emanuel (2005) who finds a 5\% increase in maximum wind speed with a $1 \%$ increase in sea surface temperature. 
Table 7: Estimated Increase in Mean Damages under Climate Change Scenarios

\begin{tabular}{|c|c|c|c|c|c|c|}
\hline & \multirow[b]{2}{*}{ b } & \multirow[b]{2}{*}{$v$} & \multirow[b]{2}{*}{$\vartheta$} & \multirow[b]{2}{*}{ SST $\left({ }^{\circ} \mathrm{C}\right)$} & \multicolumn{2}{|c|}{$\begin{array}{c}\text { Increase in Mean } \\
\text { Damages (\%) }\end{array}$} \\
\hline & & & & & 2050 & 2100 \\
\hline Nordhaus (2010) & 9.0 & 0.035 & & 2.5 & & 112.7 \\
\hline Acevedo $(2016)^{a}$ & 3.2 & 0.035 & & 2.5 & & 30.5 \\
\hline This study & 2.3 & 0.035 & & 2.5 & & 21.3 \\
\hline \multicolumn{7}{|c|}{ Using RCP2.6 temperature projections } \\
\hline Mean $\left(T=1.1^{\circ} \mathrm{C}\right)$ & 2.3 & 0.035 & 1.0 & 1.1 & 3.7 & 9.1 \\
\hline $\operatorname{Low}\left(T=0.6^{\circ} \mathrm{C}\right)$ & 2.3 & 0.035 & 1.0 & 0.6 & 2.0 & 4.9 \\
\hline $\operatorname{High}\left(T=1.6^{\circ} \mathrm{C}\right)$ & 2.3 & 0.035 & 1.0 & 1.6 & 5.4 & 13.4 \\
\hline $\begin{array}{l}\text { Mean }\left(T=1.1^{\circ} \mathrm{C}\right) \text { and } \\
\text { higher } \gamma\end{array}$ & 2.3 & 0.050 & 1.0 & 1.1 & 5.3 & 13.1 \\
\hline $\begin{array}{l}\text { Mean }\left(T=1.1^{\circ} \mathrm{C}\right) \text { and } \\
\text { lower } \theta\end{array}$ & 2.3 & 0.035 & 0.6 & 0.7 & 2.2 & 5.4 \\
\hline \multicolumn{7}{|c|}{ Using RCP8.5 temperature projections } \\
\hline Mean $\left(T=4.3^{\circ} \mathrm{C}\right)$ & 2.3 & 0.035 & 1.0 & 4.3 & 14.8 & 38.1 \\
\hline $\operatorname{Low}\left(T=2.7^{\circ} \mathrm{C}\right)$ & 2.3 & 0.035 & 1.0 & 3.0 & 9.2 & 23.1 \\
\hline $\operatorname{High}\left(T=5.8^{\circ} \mathrm{C}\right)$ & 2.3 & 0.035 & 1.0 & 5.6 & 20.3 & 53.0 \\
\hline $\begin{array}{l}\text { Mean }\left(T=4.3^{\circ} \mathrm{C}\right) \text { and } \\
\text { higher } y\end{array}$ & 2.3 & 0.050 & 1.0 & 4.3 & 21.5 & 56.5 \\
\hline $\begin{array}{l}\text { Mean }\left(T=4.3^{\circ} \mathrm{C}\right) \text { and } \\
\text { lower } \vartheta\end{array}$ & 2.3 & 0.035 & 0.6 & 2.6 & 8.8 & 22.2 \\
\hline
\end{tabular}

RCP = Representative Concentration Pathway, SST = sea surface temperature.

a Only hurricanes that made landfall in the Caribbean.

Note: The RCP 2.6 and RCP 8.5 temperature projections are adopted from Lee, Minsoo, Mai Lin Villaruel, and Raymond Gaspar. 2016. Effects of Temperature Shocks on Economic Growth and Welfare in Asia. ADB Economics Working Paper Series No. 501. Manila: Asian Development Bank. The former depicts meeting the COP21 target and the latter depicts the extreme projected temperature rise should the world fail to meet the target.

Sources: Authors' calculations based on Nordhaus, William. 2010. "The Economics of Hurricanes and Implications of Global Warming." Climate Change Economics 1 (1): 1-20.; Acevedo, Sebastian. 2016. "Gone with the Wind: Estimating Hurricane Climate Change Costs in the Caribbean.” IMF Working Paper WP/16/199.

\section{Droughts}

Compared to tropical cyclones which are "rapid onset" events, droughts are "slow onset" events that affect a wide area and can have significant economic impacts over long periods. Floods, another extreme weather event, are mostly a consequence of heavy rainfall and storm surges due to cyclones. Felbermayr and Gröschl (2014) find that an average drought reduces output by $0.01 \%$ while a top $5 \%$ strongest drought reduces it by $0.34 \%$. Loayza et al. (2012) document that in developing countries, a typical drought reduces the agricultural and industrial annual growth rate by 1 percentage point, leading to a decline of GDP growth by 0.6 percentage point per year (or 3\% over a period of 5 years). A separate study by Fomby, Ikeda, and Loayza $(2009,2013)$ found that droughts have a negative overall effect on GDP per capita growth, especially in the year of the event. The cumulative effect is $1.7 \%$ of GDP growth and $1.6 \%$ for agricultural growth. It also has a negative impact on nonagricultural growth, though delayed, up to the third year.

Although there is no consensus yet that global warming has affected the frequency and intensity of El Niño ${ }^{16}$ conditions, ${ }^{17}$ a study by the Food and Agriculture Organization of the United

16 El Niño is a band of above-average ocean surface temperatures (warm phase of the El Niño Southern Oscillation or ENSO) that naturally or periodically develops off the Pacific coast of South America and causes weather patterns and other major climatological changes around the world. The cool phase is called La Niña. 
Nations (2014) found that cycles dominated by El Niño were associated with more area affected by drought at the global agricultural level. This cycle in 1989 and 1990 caused extended droughts in 20\% and $12 \%$ of global agricultural area, respectively. The higher temperatures and droughts brought about by an El Niño event, especially severe in Asia and the Pacific, significantly increase prices of nonfuel commodities (by 5.3\% after four quarters), increase energy prices, and reduce output in agriculture, construction, and services, mostly affecting commodity-dependent countries reliant on imported food (Cashin, Mohaddes, and Raissi 2015).

\section{Philippines and Natural Disasters}

The Philippines is one of the developing Asian countries regularly hit by storms. Weather-related disasters account for $90 \%$ of annual economic damage from all natural disasters in the Philippines, making it one of the countries most exposed to climate change risks. ${ }^{a}$ Annually, an average of 19 typhoons enter the country, of which 9 or 10 typhoons make landfall (Cinco et al. 2016; Antilla-Hughes and Hsiang 2013). While there were fewer typhoons (above 115 kilometers per hour), stronger typhoons (above 150 kilometers per hour) affected the country from 1951 to 2013 (Cinco et al. 2016). Since 1990, these typhoons have been getting stronger (see box figure), with the highest maximum wind speed recorded in November 2013 during Typhoon Haiyan.

Typhoon Haiyan, a category 5 cyclone locally known as Yolanda, was the strongest typhoon to ever make landfall in the country. For a country that is used to being battered by typhoons every year, the devastation was staggering. Total damage and loss have been estimated at $\mathrm{P} 101.79$ billion (equivalent to $\$ 2.3$ billion) ${ }^{b}$ or $0.9 \%$ of gross domestic product (NEDA 2013). The economic effects are also region dependent. Relative to the bigger Luzon and National Capital Region/Metro Manila, which account for almost $75 \%$ of national output, the regions hit by Haiyan account for about $13 \%$ of gross domestic product. When two typhoons hit the Luzon regions in 2009, fourth quarter growth rate was a low 1.4\% (Jha, Quising, and Sugiyarto 2014).

Box Figure: Intensity of Typhoons at Landfall in the Philippines, 1990-2014

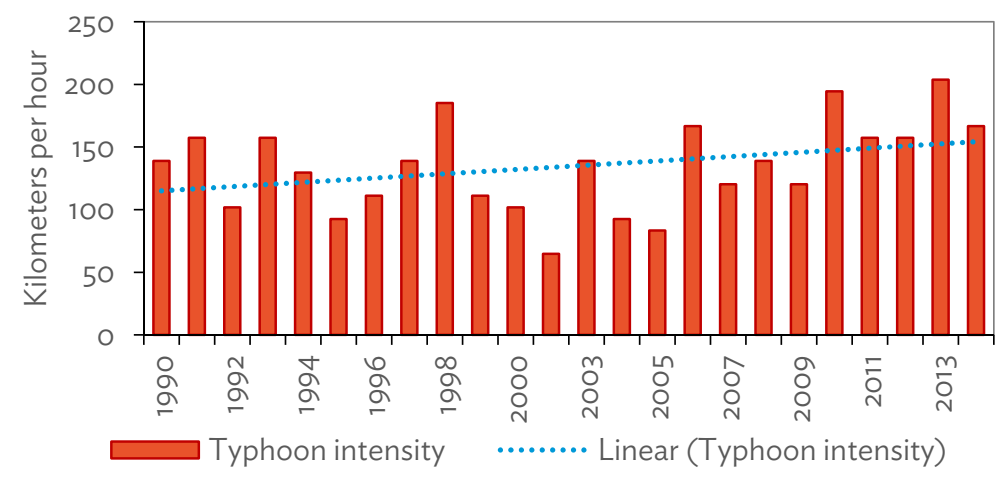

Source: Authors' calculations using data from IBTrACS version v03r08. http://www.ncdc.noaa.gov/oa/ibtracs

The poor are often the hardest hit. Typhoon Haiyan affected eight provinces, many with high levels of poverty incidence. If about $10 \%$ of the estimated 4 million people displaced and $5 \%$ of the 12 million directly affected by the typhoon become newly poor, there would be an additional 1 million poor people in the country, increasing poverty incidence by $4 \%$ (Jha, Quising, and Sugiyarto 2014). 
Box continued

The average Filipino household suffers the impacts of typhoons, with a significant decrease in income and expenditures on basic items, as well as increased infant mortality a year after typhoon exposure (see box table). One potential long-term effect is also the low birth weights which may affect later life outcomes like low education level, lower earnings, and adverse health outcomes (Morrow 2014).

Box Table: Average Effects a Year after Typhoon Exposure in the Philippines

(\%)

\begin{tabular}{lc}
\hline Outcome & Average Rate of Decrease \\
\hline Household income & $-6.6^{*}$ \\
Household expenditures & -7.1 \\
Meat & -12.5 \\
Education & -13.3 \\
Medical & -14.3 \\
Female infant mortality & 1 death per 1,000 live births \\
\hline
\end{tabular}

* Compared against average savings rate of 15\% in 2009.

Source: Antilla-Hughes, Jesse Keith, and Solomon Hsiang. 2013. "Destruction, Disinvestment, and Death: Economic and Human Losses Following Environmental Disaster." Social Science Research Network. doi:10.2139/ssrn.2220501.

The recent drought intensified by the El Niño phenomenon in 2015 was reported as one of the most powerful El Niño events in modern times. About $42 \%$ of the Philippines experienced drought with the United Nations Office for the Coordination of Humanitarian Affairs estimating around 181,687 farmers and 224,834 hectares of agricultural land were severely affected. Data from the Bureau of Fisheries and Aquatic Resources show that fishery production declined due to extreme temperatures and extended drought. Aside from agriculture, Mindanao suffered from power shortages as some of the hydroelectric dams have low water levels. By early 2016, forest fires in some mountain areas and grasslands were reported. Mount Apo, the country's highest mountain and home to forest reserves and breeding ground for the endangered monkey-eating eagle, was damaged due to raging wildfires displacing hundreds of people, including tourists, to flee from the peak on foot.

Due to the vulnerability of the country to natural disasters, especially typhoons, one may ask whether the economy has been resilient. Generally, the Philippines has been able to weather the storms with sufficient fiscal space, strong financial markets, and stable remittances (Jha, Quising, and Sugiyarto 2014). In 2013, economic growth registered at 7.2\%, one of the highest in Asia. This growth was underpinned by strong macroeconomic fundamentals such as growth in remittances and in the service sector, and high domestic demand that has shielded the Philippines from persistent disasters (World Bank 2014). However, the country has been unprepared for major disasters. Further research is thus needed to find out the effects of typhoons on the various economic sectors, both in the short and long term, and whether reconstruction efforts had significant effects on gross domestic product growth.

Notes:

a Economic damages refer to the monetary value of the negative impact of weather-related disasters on the affected economic and social sectors. Estimates calculated from raw data in IBTrACS.

b Based on Bangko Sentral ng Pilipinas (Central Bank of the Philippines) exchange rate of $\$ 1=\ngtr 44.135$, as of 12 December 2013.

Source: Authors' compilation from cited studies.

\section{B. Effects on Tourism}

Exposure to climate change and related extreme weather events affects tourism, a sector dependent on the weather and geographical location. It is expected to affect tourists' destination choices, creating different patterns of tourism flows at the regional level. Losses are expected for most developing countries while high-latitude advanced economies would gain (Farid et al. 2016; Bigano, Hamilton, and Tol 2007). 
In 28 Caribbean countries, the impact of cyclones on tourism-related income is disproportionately large (Hsiang 2010). Data on total income attributed to tourists, across all industries, are available for a shorter period from 1995 to 2006 and reveal substantial losses that persist up to 4 years relative to a trend and relative to the previous year (Table 8 ). The effect is large, estimated as high as 3.5\% of tourism receipts and $2.8 \%$ of visitors the following year. These are driven primarily by reductions in aggregate tourist visits, rather than by reductions of income per visit. In terms of effects on tourism-related industry, cyclones negatively affect the wholesale, retail, restaurants, and hotels sector, with output at $-0.9 \%$ in the year of impact, and persist in both the second and third years at $-0.3 \%$. This contrasts with positive effects on the construction industry at $1.4 \%$ from the year of the impact until the following year, due to demand brought by reconstruction and rebuilding efforts.

Table 8: Effect of Tropical Cyclones on Tourism in the Caribbean, 1995-2006

\begin{tabular}{lcccccc}
\hline & \multicolumn{3}{c}{$\begin{array}{c}\text { Deviation from Trend } \\
(\%)\end{array}$} & \multicolumn{3}{c}{$\begin{array}{c}\text { Change from Prior Year } \\
(\%)\end{array}$} \\
\hline & Receipts & Visitors & \$ per visit & Receipts & Visitors & \$ per visit \\
Cyclone, yeart & -1.6 & -0.9 & -0.6 & -1.0 & -.5 & 0.3 \\
Cyclone, year $t+1$ & -3.5 & -2.8 & -0.7 & -1.8 & -2.0 & 0.1 \\
Cyclone, year $t+2$ & -2.5 & -0.9 & -1.4 & 1.1 & 1.4 & -0.3 \\
Cyclone, year $t+3$ & -3.0 & -2.0 & -1.0 & $\ldots$ & $\ldots$ & $\ldots$ \\
Cyclone, year $t+4$ & -1.8 & -1.2 & -0.7 & $\ldots$ & $\ldots$ & $\ldots$ \\
Cyclone, year $t+5$ & -0.4 & -0.3 & -0.2 & $\ldots$ & $\ldots$ & $\ldots$ \\
Cyclone, year $t+6$ & 0.0 & -0.9 & 0.6 & $\ldots$ & $\ldots$ & $\ldots$ \\
\hline
\end{tabular}

... = data not available

Source: Hsiang, Solomon. 2010. "Temperatures and Cyclones Strongly Associated with Economic Production in the Caribbean and Central America." Proceedings of the National Academy of Sciences of the United States of America 107 (35): 15367-72.

In February 2016, Fiji took a direct hit from Cyclone Winston, the strongest to hit the country and the South Pacific, with damages estimated to exceed $\$ 500$ million or about $11 \%$ of GDP and dealing a serious blow to the tourism industry. Tourist cancellations were as high as $25 \%$ immediately following the cyclone (ADB 2016). Fiji, like most Pacific islands, relies heavily on tourism and agriculture. However, with the increasing frequency and intensity of cyclones as well as the effects of El Niño, there are increasing calls for these island states to diversify more into manufacturing and services.

\section{ADAPTATION TO NATURAL DISASTER SHOCKS}

It is feasible and cost-effective for vulnerable countries to invest heavily in adaptation, as adaptation initiatives can prevent about 3\% of GDP loss due to cyclones (Hsiang and Narita 2012). Country-level measures to lessen disaster risks include relocation or migration, climate-resilient infrastructure and improved building and fire codes, preventive measures such as early warning systems and faster emergency response systems, and other safety nets like government transfers and risk-sharing mechanisms such as development aid and disaster insurance. Adaptive capacity increases with income (Bakkensen and Mendelsohn 2016). Rich countries are better equipped because of better public services such as wide access to insurance, financing, as well as stronger institutions that provide safety nets and more resources for enforcing building and safety codes. This is a form of "adaptation deficit" which poorer countries lack and it limits their ability to adapt (Fankhauser and McDermott 2014). In the US, government-funded transfer programs such as unemployment insurance, welfare, and food stamps are some of the safety nets available to affected populations, which explains the relative 
resilience of the country to natural disasters (Deryugina 2011). Richer countries simply have more resources to protect against natural disasters (Fankhauser and McDermott 2014).

\section{A. Migration and Urbanization}

Agriculture and tourism, two production sectors that are dependent on the weather and geographical location, are the most affected by tropical cyclones. These are also the sectors that adapt the least to disaster risk. This suggests that nonagricultural and other industries can adapt more quickly through less costly strategies such as relocation (Hsiang 2010). Diversification into manufacturing is also an economic strategy especially for those sectors relying on agriculture, mostly in developing countries.

Natural disaster shocks displace at-risk populations and affect migration patterns, either temporarily or permanently. The Global Estimates Report 2015 puts the annual average number of people displaced by natural disasters at 26.4 million from 2008 to 2015 , equivalent to one person displaced every second. ${ }^{18}$ During the same period, an average of 22.5 million people are displaced by climate or weather-related disasters, or about 62,000 people per day. The same report further estimates that Asia, with 16.7 million displaced people, accounted for $87 \%$ of the global total in 2014 , with the People's Republic of China (PRC), India, and the Philippines having the highest levels of displacement in absolute terms. The persistent droughts in Bangladesh illustrate the wide-ranging effects on the country, which resulted in large-scale displacement and migration (Shamsuddoha et al. 2012).

With increasing displacement comes increase in internal migration, primarily to urban areas, especially if economic conditions worsen in the affected areas and rebuilding and reconstruction takes years. The economic development in developing Asia has been characterized by increasing incomes and rapid urbanization. The region is becoming more urban with higher wage opportunities in cities, and more globalized as its share of world output and exports expand. As economic development is shown to lead to fewer fatalities from natural disaster-related events (Kahn 2005; Bakkensen and Mendelsohn 2016; Choi 2016), it can be an important part of adaptation. Higher incomes mean the population can afford resilient housing and greater access to fast emergency response systems and financial instruments such as credit and insurance. However, whether urbanization has led to less damages and losses from disasters is unclear and the effect of migration on mitigating disaster losses is difficult to track. Choi (2016), for instance, shows that urbanization contributed slightly to the increase of disaster damages in countries of the Organisation for Economic Co-operation and Development from 1990 to 2010. On the other hand, Kahn (2014) explores the role of market innovation in cities that may lead to higher quality and cheaper products to cope with disaster risks. He further adds that human ingenuity as well as individual locational and lifestyle choices can help urban populations to adapt.

\section{B. Risk Sharing}

Unlike richer countries, poor and developing countries cope through other ways such as overseas development assistance. In one study, Yang (2008) finds that greater hurricane exposure leads to large increases in foreign aid, especially in developing countries. Low-income countries also experienced a spike in migrant remittances but a decline in bank and trade-related lending. Within 3 years after hurricane exposure, total inflows amounted to roughly four-fifths of the estimated damages

18 Annual report by the International Displacement Monitoring Centre (2015). 
in these poorer subsamples. The opposite happens in richer countries where hurricane exposure leads to inflows of new lending from multilateral institutions but which are offset by a large decline in private financial flows. Said study provides the first evidence of country risk sharing and consumption smoothing during market volatilities and of some types of private financial flows that help buffer countries from negative economic shocks or exogenous shocks such as from hurricanes.

Although international aid can mitigate the effects of natural disasters, it may not be sustainable in the long term relative to the rebuilding costs and may also reduce the incentives to invest in adaptation. These shocks significantly increase the debt-to-GDP ratio as well, putting more pressure on developing economies (Acevedo 2014). Countries with financially developed marketswith greater access to credit and high insurance penetration-are usually high-income economies and can mitigate the economic cost of natural disasters without resorting to deficit financing of expenditures (Melecky and Raddatz 2015). Felbermayr and Gröschl (2014) show that a financially open economy can lessen the negative effects on GDP per capita. ${ }^{19}$ On average, output losses for financially less developed countries account for about $2 \%-10 \%$ of GDP. This further reinforces the assumption that adaptive capacity increases with income.

Insurance can also be an important form and substitute to cope with disaster risk, especially for developing countries. It offers a way to reduce the costs of disaster damage without raising taxes or reducing spending (Laframboise and Acevedo 2014). However, poor countries often lack access to disaster insurance. The World Bank's Global Index Insurance Facility is a new and innovative approach that addresses the lack of access to insurance in developing countries (IFC 2016). This index-based (or parametric index) insurance for loss of assets and capital due to natural disaster shocks is based on deviations from the normal values of weather parameters such as wind speed for tropical cyclones, precipitation and rainfall for droughts, and temperature for extreme temperature and heat waves. A multidonor trust fund, it has so far funded private sector insurance initiatives in Indonesia, Sri Lanka, and Papua New Guinea.

Catastrophic risk finance, or disaster risk finance, can also mitigate against natural disaster risks in Asia, as part of a comprehensive disaster risk management in the region. As early as 2008, the Asian Development Bank has been at the forefront of setting up this multilateral risk-sharing mechanism, patterned after the Caribbean Catastrophe Risk Insurance Facility. Opportunities exist for these types of risk sharing in the Asian region and are viable if done through regional public-private partnerships, albeit lacking capacity and resources (ADB 2009). The Pacific Catastrophe Risk Insurance Pilot started in 2013 is an example of an ongoing program that aims to increase the capacity of small Pacific island states for postdisaster financing and reconstruction needs.

In the 1990s, catastrophe bonds were issued to hedge against disaster-related risks. Pension funds and large institutional investors bought about four-fifths of issued catastrophe bonds in 2014, with higher returns than other securities. The outstanding amount is about $\$ 25$ billion with about $\$ 8.8$ billion issued in 2014 alone (Farid et al. 2016). However, their long maturity, unwillingness of investors to take on the risks, and difficulties in estimating potential losses have dissuaded investors.

19 The authors used the Chin-Ito financial openness indicators. A disaster year belonging to the 95th percentile of the weighted disaster index produces a GDP per capita loss of $2.12 \%$ if the country is financially closed (Chinn-Ito index of 0.1 ). With an intermediate openness of 0.4 , the damage of the same disaster intensity is $1.43 \%$ of GDP per capita, while it is $0.5 \%$ for financially open countries (Chinn-Ito index of 0.8 ). A disaster year in the 75th percentile reduces GDP per capita by $0.47 \%, 0.32 \%$, and $0.11 \%$ for countries with low (0.1), intermediate (0.4), and high (0.8) levels of financial openness, respectively (Felbermayr and Gröschl 2014). 
They do not see the appeal of an investment whose name includes "catastrophe" (Lewis 2007). The huge losses of the insurance industry during Hurricane Katrina also tempered investors' eagerness to invest. One thing they have discovered, however, is that a Katrina-type event went from a 1-in-40-year event to a 1-in-20-year event. The risk from natural disasters has doubled.

\section{POLICY RECOMMENDATIONS}

Recognizing that climate change compromise development, numerous efforts on climate change adaptation and mitigation have been identified over the past several years. One of the targets of Sustainable Development Goal 13 is "to strengthen resilience and adaptive capacity to climate-related hazards and natural disasters in all countries." ${ }^{\circ}$ Designs and policy measures are country specific and very much dependent on each national circumstances and experiences. These measures must be integrated into national disaster plans as well as in medium- and long-term economic projections. International recommendations and policies on climate change must have proper support from the national government for them to be effectively and efficiently implemented.

International aid played a key role in the construction of disaster-resilient infrastructure in developing countries and development of resilient crop varieties. At the national level, policies and structures for disaster response are in place and preparedness is crucial to prevent large losses from natural disasters. In coordination with the private sector, governments must establish and invest more on early warning systems for natural hazards to warn and prevent large damages. Coordinated policies and mechanisms must be in place in order for the public sector, private sector, and other humanitarian organizations and affected local governments to achieve a proper and faster response and delivery of relief goods and services.

Redirecting investments toward adaptation measures as well as additional financing for climate-resilient initiatives can be done to cope with disasters. Developed and developing economies have to pool resources to better provide assistance both to prevent large damages and losses as well as in faster rebuilding.

Governments must also establish and maintain information management systems to properly identify and prioritize adaptive measures and create their own local adaptation and disaster risk reduction plans. They can further disseminate information and adaptation measures to help improve knowledge on the impact of climate change by mainstreaming climate awareness into the basic education curriculum. Capacity building down to the local level should be conducted especially in disaster-prone areas.

\section{CONCLUSION}

Natural disaster shocks, such as typhoons and droughts, have the potential to undo years of development by destroying both human and physical capital. Data from existing studies as well as from global disaster databases point to increasing damages and losses. Using exogenous indicators such as wind speed, temperature, and rainfall patterns, robust estimates point to significant short- and long-

20 Sustainable Development Goal 13: Take urgent action to combat climate change and its impacts. See UN website at http://www.un.org/sustainabledevelopment/climate-change-2/ 
term losses to per capita growth, from as low as $0.1 \%-14.9 \%$ for typhoons and $0.01 \%-3 \%$ for droughts. The extent of output volatility is felt not only in the year of impact but in succeeding years as well, up to 5 years for droughts and 20 years for typhoons. In Asia, the elasticity of damages with respect to maximum wind speed is about 2 . This would be higher if further research takes into account other factors such as storm surge and rainfall as well as including socioeconomic factors in future projections.

Current research points to more frequent and stronger weather shocks as the earth gets warmer. Together with temperature variation and sea level rise, the risks from climate-related natural disasters increase. In developing Asia, the macroeconomic impacts from both extreme temperatures and extreme weather events can significantly dampen the region's growth prospects and increase inequality. Vulnerable populations from disaster-prone areas are mostly the poor who have the least access to resilient housing, are most affected by volatile food prices through its effects on agricultural production, and have the least access to financial instruments such as credit and insurance.

Since the poor suffer the most from the effects of natural disaster shocks, adaptation efforts should address needs such as relocation, resilient infrastructure, new resistant crops, and government transfers to more sustainable ex ante strategies and risk-sharing mechanisms like disaster insurance. 


\section{REFERENCES}

Acevedo, Sebastian. 2014. "Debt, Growth and Natural Disasters: A Caribbean Trilogy." IMF Working Paper WP/14/125.

_. 2016. "Gone with the Wind: Estimating Hurricane Climate Change Costs in the Caribbean." IMF Working Paper WP/16/199.

Adedeji, Olumuyiwa, Janna Gieck-Bricco, and Vera Kehayova. 2016. "Natural Disasters and Food Crises in Low Income Countries: Macroeconomic Dimensions.” IMF Working Paper WP/16/65.

Antilla-Hughes, Jesse Keith, and Solomon Hsiang. 2013. "Destruction, Disinvestment, and Death: Economic and Human Losses Following Environmental Disaster." Social Science Research Network. doi: 10.2139/ssrn.2220501.

Asian Development Bank (ADB). 2009. Natural Catastrophe: Risk Insurance Mechanisms for Asia and the Pacific-Main Report. Manila.

2016. Asian Development Outlook 2014: Asia's Potential Growth. Manila.

Bakkensen, Laura, and Robert Mendelsohn. 2016. "Risk and Adaptation: Evidence from Global Hurricane Damages and Fatalities." Journal of the Association of Environmental and Resource Economists 3 (3): 555-87.

Bigano, Andrea, Jacqueline Hamilton, and Richard Tol. 2007. "The Impact of Climate Change on Domestic and International Tourism: A Simulation Study." The Integrated Assessment Journal 7 (1): $25-49$.

Bouwer, Laurens, and Wouter Botzen. 2011. "How Sensitive are US Hurricane Damages to Climate? Comment on a Paper by W. D. Nordhaus." Climate Change Economics 2 (1): 1-7.

Burke, Marshall, Solomon Hsiang, and Edward Miguel. 2015. "Global Non-linear Effect of Temperature on Economic Production.” Nature 527 (7577): 235-39.

Cabezon, Ezequiel, Leni Hunter, Patrizia Tumbarello, Kazuaki Washimi, and Yiqun Wu. 2015. "Enhancing Macroeconomic Resilience to Natural Disasters and Climate Change in the Small States of the Pacific." IMF Working Paper WP/15/125.

Cashin, Paul, Kamiar Mohaddes, and Mehdi Raissi. 2015. "Fair Weather or Foul? The Macroeconomic Effects of El Niño.” IMF Working Paper WP/15/89.

Cerra, Valerie and Sweta Chaman Saxena. 2008. "Growth Dynamics: The Myth of Economic Recovery." American Economic Review 98(1): 439-457.

Choi, Choongik. 2016. "Does Economic Growth Really Reduce Disaster Damages? Index Decomposition Analysis for the Relationship between Disaster Damages, Urbanization and Economic Growth and its Implications." International Journal of Urban Sciences 20 (2): 188205. 
Cinco, Thelma, Rosalina de Guzman, Andrea Monica Ortiz, Rafaela Jane Delfino, Rodel Lasco, Flaviana Hilario, Edna Juanillo, Rose Barba, and Emma Ares. 2016. "Observed Trends and Impacts of Tropical Cyclones in the Philippines." International Journal of Climatology 36 (14): 4638-50. doi:10.1002/joc.4659.

Collins, Mat, S. Soon-II An, Wenju Cai, Alexandre Ganachaud, Eric Guilyardi, Fei-Fei Jin, Markus Jochum, Matthieu Lengaigne, Scott Power, Axel Timmermann, Gabe Vecchi and Andrew Wittenberg. 2010. "The Impact of Global Warming on the Tropical Pacific Ocean and El Niño." Nature Geoscience 3 (6): 391-97.

Dell, Melissa, Benjamin Jones, and Benjamin Olken. 2012. "Temperature Shocks and Economic Growth: Evidence from the Last Half Century." American Economic Journal: Macroeconomics 4 (3): 66-95.

Deryugina, Tatyana. 2011. "The Dynamic Effects of Hurricanes in the US: The Role of Non-Disaster Transfer Payments." MIT Center for Energy and Environmental Policy Research CEEPR WP 2011-007.

Emanuel, Kerry. 2005. "Increasing Destructiveness of Tropical Cyclones over the Past 30 Years." Nature 436: 686-88.

EM-DAT: The OFDA/CRED International Disaster Database. Brussels, Belgium: Catholic University of Louvain. http://www.emdat.be/

Fankhauser, Samuel, and Thomas McDermott. 2014. "Understanding the Adaptation Deficit: Why Are Poor Countries More Vulnerable to Climate Events than Rich Countries?" Global Environmental Change 27 (1): 9-18.

Farid, Mai, Michael Keen, Michael Papaioannou, Ian Parry, Catherine Pattillo, and Anna TerMartirosyan. 2016. "After Paris: Fiscal, Macroeconomic, and Financial Implications of Climate Change.” IMF Staff Discussion Note SDN/16/01.

Felbermayr, Gabriel, and Jasmin Gröschl. 2014. "Naturally Negative: The Growth Effects of Natural Disasters.” Journal of Development Economics 111: 92-106.

Fomby, Thomas, Yuki Ikeda, and Norman Loayza. 2009. "The Growth Aftermath of Natural Disasters." The World Bank Development Research Group and Global Facility for Disaster Reduction and Recovery Policy Research Working Paper 5002.

2013. "The Growth Aftermath of Natural Disasters." Journal of Applied Econometrics 28 (3): 412-34.

Food and Agriculture Organization of the United Nations. 2014. Understanding the Drought Impact of El Niño on the Global Agricultural Areas: An Assessment Using FAO's Agricultural Stress Index (ASI). Rome.

Hallegatte, Stephane, Mook Bangalore, Laura Bonzanigo, Marianne Fay,Tamaro Kane, Ulf Narloch, Julie Rozenberg, David Treguer, and Adrien Vogt-Schilb. 2015. Shock Waves: Managing the Impacts of Climate Change on Poverty. Washington, DC: World Bank. 
Herring, Stephanie, Martin Hoerling, James Kossin, Thomas Peterson, and Peter Stott. 2015. "Explaining Extreme Events of 2014 from a Climate Perspective." Special Supplement to the Bulletin of the American Meteorological Society 96 (12): 1-172.

Hsiang, Solomon. 2010. "Temperatures and Cyclones Strongly Associated with Economic Production in the Caribbean and Central America." Proceedings of the National Academy of Sciences of the United States of America 107 (35): 15367-72.

Hsiang, Solomon, and Amir Jina. 2014. "The Causal Effect of Environmental Catastrophe on Long Run Economic Growth: Evidence from 6,700 Cyclones.” National Bureau of Economic Research Working Paper No. 20352.

Hsiang, Solomon, and Daiju Narita. 2012. "Adaptation to Cyclone Risk: Evidence from the Global Cross-section.” Climate Change Economics 3 (2): 1-28.

Intergovernmental Panel on Climate Change (IPCC). 2012. "Summary for Policymakers." In Managing the Risks of Extreme Events and Disasters to Advance Climate Change Adaptation, edited by C. B. Field, V. Barros, T. F. Stocker, D. Qin, D. J. Dokken, K. L. Ebi, M. D. Mastrandrea, K. J. Mach, G.K. Plattner, S. K. Allen, M. Tignor, and P. M. Midgley. A Special Report of Working Groups I and II of the Intergovernmental Panel on Climate Change. Cambridge, UK, and New York, NY: Cambridge University Press.

2014. Fifth Assessment Report. Geneva. http://www.ipcc.ch/report/ar5/

International Best Track Archive for Climate Stewardship (IBTrACS). http://www.ncdc.noaa.gov/ oa/ibtracs

International Displacement Monitoring Centre. 2015. Global Estimates 2015: People Displaced by Disasters. Geneva.

International Federation of Red Cross and Red Crescent Societies (IFRC). 2016. "Philippines: Drought and Dry Spells - Information Bulletin No. 1." April 29. http://www.ifrc.org/docs/Appeals/ 16/IBPHdr290416.pdf

International Finance Corporation (IFC). 2016. "Global Index Insurance Facility." http://www.ifc.org/wps/wcm/connect/industry_ext_content/ifc_external_corporate_site/ind ustries/financial+markets/retail+finance/insurance/global+index+insurance+facility

Jha, Shikha, Pilipinas Quising, and Guntur Sugiyarto. 2014. "Economic and Poverty Impacts of Typhoon Haiyan: A Policy Note." Unpublished.

Kahn, Matthew. 2005. "The Death Toll from Natural Disasters: The Role of Income, Geography, and Institutions." The Review of Economics and Statistics 87 (2): 271-84.

- 2014. "Climate Change Adaptation: Lessons from Urban Economics." National Bureau of Economic Research Working Paper No. 20716.

Karim, Azreen. 2016. "The Household Response to Persistent Natural Disasters: Evidence from Bangladesh.” Victoria Business School SEF Working Paper 05/2016. 
Klomp, Jeroen, and Kay Valckx. 2014. "Natural Disasters and Economic Growth: A Meta-analysis." Global Environmental Change 26: 183-95.

Knapp, Kenneth, Michael Kruk, David Levinson, Howard Diamond, and Charles Neumann. 2010. “The International Best Track Archive for Climate Stewardship (IBTrACS): Unifying Tropical Cyclone Best Track Data." Bulletin of the American Meteorological Society 91: 363-76.

Knutson, Thomas, John Mcbride, Johnny Chan, Kerry Emanuel, Greg Holland, Chris Landsea, Isaac Held, James Kossin, A. K. Srivastava, and Masato Sugi. 2010. "Tropical Cyclones and Climate Change." Nature Geoscience 3: 157-63.

Laframboise, Nicole, and Sebastian Acevedo. 2014. "Man versus Mother Nature." Finance \& Development 51 (1): 44-47.

Lee, Minsoo, Mai Lin Villaruel, and Raymond Gaspar. 2016. "Effects of Temperature Shocks on Economic Growth and Welfare in Asia." ADB Economics Working Paper Series No. 501. Manila: Asian Development Bank.

Lewis, Michael. 2007. "In Nature's Casino." The New York Times Magazine, August 26. http://www.nytimes.com/2007/08/26/magazine/26neworleans-t.html?_r=0

Loayza, Norman, Educardo Olaberría, Jamele Rigolini, and Luc Christiaensen. 2012." Natural Disasters and Growth: Going Beyond the Averages." World Development 40 (7): 1317-36.

Mei, Wei, Shang-Ping Xie, Francois Primeau, James McWilliams, and Clauia Pasquero. 2015. "Northwestern Pacific Typhoon Intensity Controlled by Changes in Ocean Temperatures." Science Advances 1 (4), e1500014. doi:10.1126/sciadv.1500014.

Melecky, Martin, and Claudio Raddatz. 2015. "Fiscal Responses after Catastrophes and the Enabling Role of Financial Development.” The World Bank Economic Review 29 (1): 129-49.

Mendelsohn, Robert, Kerry Emanuel, Shun Chonabayashi, and Laura Bakkensen. 2012. "The Impact of Climate Change on Global Tropical Cyclone Damage.” Nature Climate Change 2: 205-209.

Morrow, Sarah. 2014. "Typhoons and Lower Birth Weight in the Philippines." University of San Francisco. http://repository.usfca.edu/thes/89

National Disaster Risk Reduction and Management Council (NDRRMC). 2013. "NDRRMC Update: Final Report re Effects of Typhoon 'Yolanda' (Haiyan)." November 6-9. http://ndrrmc.gov.ph/attachments/article/1329/FINAL_REPORT_re_Effects_of_Typhoon_ YOLANDA_(HAIYAN)_06-09NOV2013.pdf

National Economic and Development Authority (NEDA). 2013. "Reconstruction Assistance on Yolanda (RAY): Build-Back-Better.” December 16. http://yolanda.neda.gov.ph/reconstructionassistance-on-yolanda-ray-build-back-better/

National Oceanic and Atmospheric Administration (NOAA). "Saffir-Simpson Hurrican Wind Scale." http://www.nhc.noaa.gov/aboutsshws.php 
Nordhaus, William. 2010. "The Economics of Hurricanes and Implications of Global Warming." Climate Change Economics 1 (1): 1-20.

Raddatz, Claudio. 2007. "Are External Shocks Responsible for the Instability of Output in Low-Income Countries?” Journal of Development Economics 84 (1): 155-87.

Reinhart, Carmen, and Kenneth Rogoff. 2009. "The Aftermath of Financial Crises." American Economic Review 99 (2): 466-72.

Romer, Christina, and David Romer. 2010. "The Macroeconomic Effects of Tax Changes: Estimates Based on a New Measure of Fiscal Shocks.” American Economic Review 100 (3): 763-801.

Schmidt, Silvio, Claudia Kemfert, and Peter Höppe. 2010. "The Impact of Socio-Economics and Climate Change on Tropical Cyclone Losses in the USA." Regional Environmental Change 10 (1): 13-26.

Shamsuddoha, Md, SM Munjural Hannan Khan, Sajid Raihan, and Tanjir Hossain. 2012. "Displacement and Migration from Climate Hot-spots in Bangladesh: Causes and Consequences." ActionAid Bangladesh. https://unfccc.int/files/adaptation/groups_committees/loss_and_damage_executive _committee/application/pdf/displacement_and_migration_in_bangladesh.pdf

United Nations. "Goal 13: Take urgent action to combat climate change and its impact." http://www/un.org/sustainabledevelopment/climate-change-2/

United Nations Universtiy, Institute for Environment and Human Security. World Risk Report. http://www.worldriskreport.org/

Victoriano, Danila. 2015. "Safeguarding Development from Natural Disasters." World Bank. February 4. http://www.worldbank.org/en/news/feature/2015/02/04/what-does-it-take-to-bringresilience-to-scale

World Bank. World Development Indicators. http://data.worldbank.org/data-catalog/worlddevelopment-indicators

World Bank. 2014. "Philippine Economic Update 2014: Pursuing Inclusive Growth through Sustainable Reconstruction and Job Creation." March. http://www.worldbank.org/en/country/philippines/ publication/philippine-economic-update-2014-pursuing-economic-growth-through-sustainable -reconstruction-and-job-generation

2016. "Extreme Weather Events in a Changing Climate." http://econ.worldbank.org/WBSITE/ EXTERNAL/EXTDEC/EXTRESEARCH/EXTPROGRAMS/EXTEAER/0,,contentMDK:228587 49 pagePK:64168182 piPK:64168060 theSitePK:5991650,00.html\#cyclone

Yang, Dean. 2008. "Coping with Disaster: The Impact of Hurricanes on International Financial Flows, 1970-2002." The B.E. Journal of Economic Analysis \& Policy 8 (1): 1-45. 


\section{Natural Disaster Shocks and Macroeconomic Growth in Asia: Evidence for Typhoons and Droughts}

Under a looming threat of climate-related extreme events, estimates of the effects of typhoons and droughts show declines in national incomes compared to predisaster trends persisting up to 2 decades. In Asia, damages from typhoons double relative to a unit increase in wind speed with mean damages projected to rise from $5 \%$ to $50 \%$. This could undo development gains in vulnerable developing Asian economies and affect mostly the poor. Relocation, social safety nets, and disaster insurance or similar ex ante mechanisms are needed to cope with increased disaster risks.

\section{About the Asian Development Bank}

ADB's vision is an Asia and Pacific region free of poverty. Its mission is to help its developing member countries reduce poverty and improve the quality of life of their people. Despite the region's many successes, it remains home to a large share of the world's poor. ADB is committed to reducing poverty through inclusive economic growth, environmentally sustainable growth, and regional integration.

Based in Manila, ADB is owned by 67 members, including 48 from the region. Its main instruments for helping its developing member countries are policy dialogue, loans, equity investments, guarantees, grants, and technical assistance. 